超高分子量ポリプロピレン延伸テープのキセノンアーク灯光照射による強度低下

\author{
松山東雲短期大学 池田由貴子 \\ お茶の水女子大学 人間文化創成科学研究科 駒城素子
}

\title{
The Lowering of Strength of the Drawn Tape of Ultra-high-molecular-weight Polypropylene by the Irradiation with Xenon Arc Lamp
}

\author{
Yukiko Ikeda ${ }^{* 1}$ and Motoko Komaki ${ }^{* 2}$ \\ ${ }^{* 1}$ Matsuyama Shinonome Junior College, 3-2-1, Kuwabara, Matsuyama, Ehime 790-8531, Japan \\ ${ }^{* 2}$ Graduate School of Humanities and Sciences, Ochanomizu University, 2-1-1, Otsuka, Bunkyo-ku, \\ Tokyo 112-8610, Japan
}

\begin{abstract}
It was investigated from a practical point of view the influence of light irradiation on the strength of drawn tape of ultra-high-molecular-weight polypropylene (UHMW-PP) prepared by the gel-casting (GC) method and the gellike spherulite press (GSP) method. Consequently, it was found that the irradiated GC sheets prepared from 1, 2, 4 and $6 \mathrm{wt} . \%$ solutions had different tendencies on the change of strength by ultra-drawing. The ratio of lowering of strength increased with increase in draw ratio of both GC and GSP sheets, especially GC sheet.
\end{abstract}

(Received 10 September, 2009 ; Accepted 6 November, 2009)

\section{1. 緒 言}

高強度・高弾性率高分子繊維は, ロープ・ネット・テ ント・工事用シートなどとして屋外環境で使用されるこ とが多く，その使用期間が長期に亘る場合もある。また， レジャーやスポーツの普及により，われわれの消費生活 においても登山やスキー・マリンレジャー・釣りなどの スポーツ用あるいはアウトドア用のウェアや用具の材料 として, 屋外で強い紫外線を浴びながら, 過酷な使用状 況に耐えうる強さが求められる場合がある.このような 用途においては, 材料の耐光性が重要である. 現在, 高 強度・高弾性率高分子繊維の代表は超高分子量ポリエチ レン纎維であり, 強度・弾性率のみならず耐光性におい ても優れた性能を示している $[1]$.

筆者らは以前, 高分子溶液から溶液濃度または溶液冷 却速度を変えて作製した超高分子量ポリプロピレンシー トを様々な倍率に延伸して, 延伸に伴う強度・弾性率の 変化を測定した. 溶液濃度, 溶液冷却速度を変えること により，分子間絡み合い密度の異なるシートが作製され ると考えられ, 延伸に伴う強度・弾性率の上昇挙動を分 子間絡み合い密度に観点をおいて考察した $[2,3,4]$. その 結果, いずれの試料も, 延伸に伴って強度・弾性率が増 大する傾向が見られた。詳細には, 低延伸倍率では強度・ 弾性率は延伸に伴って直線的に上昇し, やがて上昇が緩 やかになり, 最終的には変化しなくなった.これら延伸 テープの最大測定值は、強度 $1.06 \mathrm{GPa} 、$ 弾性率 $26.6 \mathrm{GPa}$ で
あった，分子間絡み合い密度との関連では, 溶液を徐冷 して分子間絡み合い密度を小さくした試料は, 溶液を急 冷して作製した試料よりも強度・弾性率の初期上昇率が 小さい結果となったが, 溶液濃度を変えていずれも溶液 を急冷して作製した試料間では強度・弾性率上昇の差が 認められなかった。このような結果になった理由は, 試 料の分子間絡み合い密度の違いから推察することができ た.

ポリプロピレンの耐光性はポリエチレンよりかなり小 さく, 実用化の場合には, 紫外線劣化が問題になると考

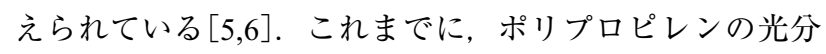
解に対する化学構造ならびに合成法の影響 [7], UV 分解 ポリプロピレン及びポリカーボネートの分解深さプロ フィルと破壊に及ぼす安定剤の影響[8], PP と HDPE 織 物の紫外線曝露研究 [9]など, 既に数多くの報告があるが、 超高分子量ポリプロピレン延伸テープの延伸に伴う耐光 性の変化についての研究は見当たらない。そこで筆者ら は, 超高分子量ポリプロピレン延伸テープの実用的観点 から, シート調製時の分子間絡み合い密度の相違や延伸 倍率と関係づけて, 超高分子量ポリプロピレン延伸テー プの強度におよぼす光照射の影響を調べた。

\section{2. 実験方法}

\section{1 試料作製}

以下の方法で, 高分子溶液からシート状物質を作製し 
た. その際, 溶液濃度と溶液冷却速度を変えることで, 分子間絡み合い密度の異なるシートを 5 種類作製した. そのうち 4 種類は「ゲルキャスト法 (以下, GC 法と略す)」 とし, 残り 1 種は「ゲル状球晶プレス法(以下, GSP 法と 略す)」を適用した. 次いでこれらシートを各種倍率に延 伸した。

1）高分子ゲル物質およびゲル状球晶の調製

所定量の超高分子量ポリプロピレン粉末(以下, UHMW -PP と略す) (重量平均分子量 $1.8 \times 10^{6}$, 徳山曹達(株)(現 · (株)トクヤマ)製)とその $0.5 \mathrm{wt} . \%$ の酸化防止剤 (BHT) (ヨシ ノックス K569A) を溶媒(デカリン(林純薬工業(株)) $)$ 中 $160^{\circ} \mathrm{C}$ で溶解して，1，2，4，6wt.\%の高分子溶液を調製し た.

これらの溶液をそれぞれ高温のまま, 冷媒(ドライアイ ス+メタノール)で周りを取り囲んだステンレス容器に流 し込んで急冷し，4種のゲル物質を作製した。一方， $2 \mathrm{wt} . \%$ 溶液についてはさらに別に室温にて徐冷し, 一晚放置し てデカリン中でゲル状球晶を生成させた。

\section{2) シート成形}

金属ネットと濾紙を敷いて溶媒(デカリン)だけが枠外 へ流れ出るようにしたプレス型枠 $(10 \mathrm{~cm} \times 10 \mathrm{~cm})$ に急冷ゲ ル物質またはゲル状球晶の分散液を流し込み, 卓上プレ ス機 (TABLE TYPE TEST PRESS SA-302-I, テスター産業) を用いて室温, $50 \mathrm{kgf} / \mathrm{cm}^{2}$ でプレスし， 1 辺が $10 \mathrm{~cm}$ の正方 形のシートを作製した。そのシートを減圧乾燥機(ISHII VACUUM SAMPLE OVEN HD-TF)にて室温で数時間減圧 乾燥し, デカリン含有率が 3〜 5wt.\%となるよう調製した.

\section{3）シートの 2 段延伸}

これらのシートを延伸してテープ状にし, それから強 度測定用試料を作製した. その際，延伸を 2 回に分けて 行う二段延伸法を採用した。

1 段および 2 段延伸温度は, TG-DSC 装置を用いて测定 した未延伸シートと 10 倍延伸テープの融解開始温度に近 い温度 $\left(130^{\circ} \mathrm{C}, 150^{\circ} \mathrm{C}\right)$ をそれぞれ採用した。また延伸倍 率は, 試料の延伸前後のデニール比から求めた.

試料の延伸は, 本研究用に設計した加熱装置付き一軸 引っ張り試験機(岩本製作所製)を用いて, 以下の手順で 行った.

未延伸シートから短冊状の小片 (長さ $40 \mathrm{~mm}$, 幅 $10 \mathrm{~mm}$ ) を切り出しデニールを測定する.つかみ間距離を $20 \mathrm{~mm}$ として引っ張り試験機に小片をセットし, 加熱炉の温度 が $130^{\circ} \mathrm{C}$ に達したら, 10 分間の予備加熱後, 変形速度 50\%/min でその小片を 10 倍まで延伸してテープ状にする 次に, 延伸したテープを $40 \mathrm{~mm}$ の長さの小片にカットし てデニールを測定した後, つかみ間距離を $20 \mathrm{~mm}$ として 引っ張り試験機にセットし, 加熱炉の温度が $150^{\circ} \mathrm{C} に$ 達 したら, 10 分間の予備加熱後, 変形速度 50\%/min でその 小片を所定の延伸倍率になるよう再延伸して強度測定用 試料を得た。

本報では，GC 法にて作製した未延伸シートおよびその
延伸テープを「GC 試料」，GSP 法にて作製した未延伸シー トおよびその延伸テープを「GSP 試料」と呼ぶことにし た. 試料の厚さは，未延伸シートはいずれも $0.5 \mathrm{~mm}, 1$ 段 延伸終了時 (10 倍延伸テープ)は $0.08 \sim 0.18 \mathrm{~mm}, 2$ 段延伸 して様々な倍率に延伸することにより $0.03 \sim 0.08 \mathrm{~mm} に$ なっていた。

\section{2 キセノンアーク灯光照射}

本研究では, 耐光性測定用照射光として, 太陽光に比 較的近いとされるキセノンアーク灯光を使用し, JIS L 0843 : 2006 「キセノンアーク灯光に対する染色堅ろう度 試験方法 A 法 (通常温度法)」[10]および JIS L 0891: 2007 「キセノンアーク灯光又はサンシャインカーボンアーク 灯光を用いた促進耐候堅ろう度試験方法」[11]を参考に試 験を行った。 すなわち, ブラックパネル温度 $63 \pm 2{ }^{\circ} \mathrm{C}$, 槽 内温度 $38 \pm 3{ }^{\circ} \mathrm{C}$, 相対湿度 $50 \pm 5 \%$, 放射照度 $50 \mathrm{~W} / \mathrm{m}^{2}$ に 設定した $2.5 \mathrm{~kW}$ キセノンウェザーメーター(スガ試験機(侏) 製, X25 型)に試料をセットし, キセノンアーク灯光を 50 時間連続照射した。

\section{3 強度測定}

強度測定は, 等速伸長型引っ張り試験機(島津オートグ ラフ DSS-500 形)を用いて行った.

延伸テープの延伸倍率を測定し, 強度測定用サンプル がほぼ 200 デニールになるよう延伸テープを延伸方向に 裂いて小片を作製し, つかみ間距離 $20 \mathrm{~mm}$, 変形速度 50\%/min, 室温でサンプルが破断するまで引っ張り, その S-S 曲線からサンプルの単位デニール当たりの破断強度 (GPa)を算出した.

同一延伸テープから採取したサンプルでは, ポリプロ ピレンの極限強度を探るため, 最も高い測定值を採用し た $[2,3,4]$. なお, 同一試料サンプル間では強度測定值に 大きなバラツキは見られなかった. また, 未延伸露光シー トはサンプリング中に砕けてしまい, 強度測定ができな かった. そのため露光試料の強度は, 延伸倍率 10 倍以上 の試料のみ測定した。

\section{3. 結果と考察}

\section{1 試料の延伸倍率および露光と強度の関係}

$\mathrm{GC}$ 試料の延伸倍率と強度との関係におよぼす光照射の 影響を見ると (Fig. 1), 露光試料の強度は未露光試料の半 分以下に低下している. 4,6wt.\%GC 試料を露光すると, その強度は延伸倍率 20 倍付近までは延伸倍率の増加に 伴って上昇する傾向も見られるが, 全体的には高延伸倍 率でも強度は上昇せず, 結果的に延伸倍率が大きくなる に伴って強度低下の割合が大きくなっていく傾向が見ら れる.さらに, 露光試料では調製時の溶液濃度の影響が 大きく, しかもデータの変動が見られる. この点が, 急 冷調製試料の露光の有無による大きな相違である.

Fig. 2 は，2wt.\%溶液から作製した徐冷 GSP 試料につい て, その強度におよぼす光照射の影響を示したものであ 


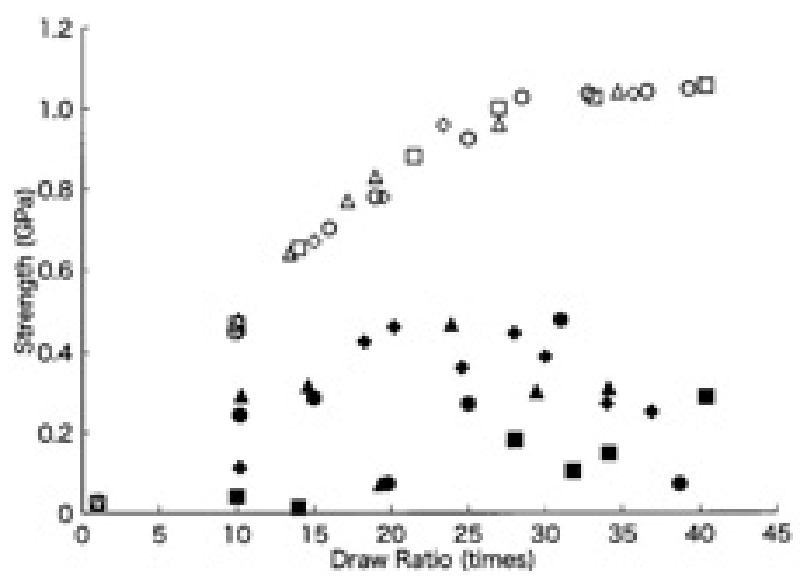

Fig. 1 Maximum tensile strength versus draw ratio of the irradiated and non-irradiated GC sheets of UHMW-PP prepared from 1wt.\% ( $\square, \square)$, 2wt.\% $(\odot, \bigcirc), 4 w t . \%(\boldsymbol{\Delta}, \triangle)$ and 6wt.\% $(\bullet$, $\diamond$ ) solutions (The filled symbols are assigned to the irradiated sheets and the open symbols are assigned to the non-irradiated sheets).

る. 露光試料では, 延伸倍率 28 倍付近までは強度は直線 的に上昇するが, 42 倍では 28 倍時よりも強度がやや低下 している. GC 試料と同様に, 延伸倍率が増大すると光照 射により強度が低下する割合が大きくなり, 光照射の影 響が大きく現れるが， GC 試料と比較すると強度低下は小 さい.

一般に, 試料の厚さ (太さ)によって光透過率が異なる ため，それが強度測定值に影響をおよぼすと考えられる。 今回は非常に薄く幅の狭い試料を使用したが, 屋外での 長期間使用を前提とした実用製品としてはロープ・ネッ ト等のように, 実際にはもっと太いものが想定され，そ のような場合の強度低下は今回の測定結果よりも小さい と考えられる.

\section{2 露光 GC 試料と露光 GSP 試料の強度の比較}

未露光試料では, 調製法によって延伸による強度の上

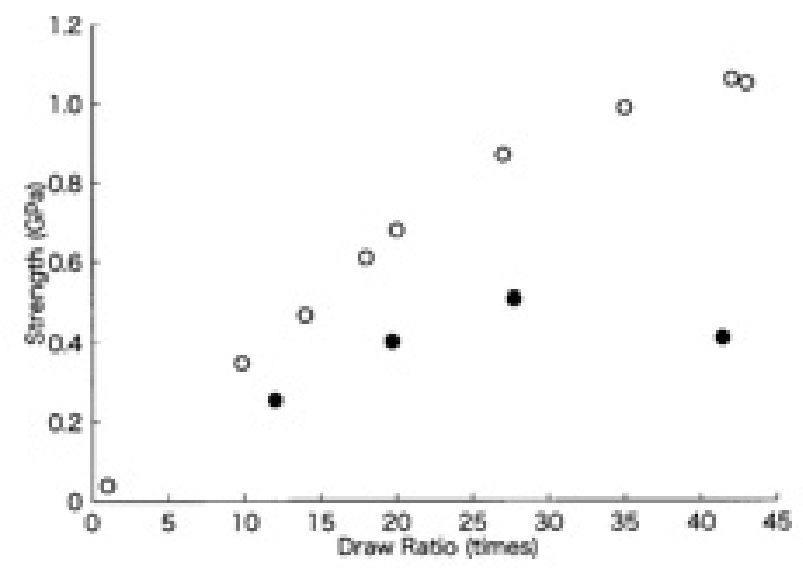

Fig. 2 Maximum tensile strength versus draw ratio of the irradiated $(O)$ and non-irradiated $(\bigcirc)$ GSP sheets of UHMW-PP prepared from $2 \mathrm{wt} . \%$ solutions.
昇率が相違し, GC 法の方がやや大きい[3]. 一方露光試 料では, 徐冷の GSP 試料の強度データには GC 試料のよ うな変動が見られず，また，強度自体 GC 試料よりやや 大きい. したがって，ここでも露光すると溶液冷却速度 の影響が強度に現れることがわかる.

\section{$3.3 \mathrm{GC}$ 法によるシート成形時の溶液濃度と強度と の関係におよぼす光照射の影響}

Fig. 1 に示した通り, 未露光 $\mathrm{GC}$ 試料の強度は, 溶液濃 度ではなく延伸倍率に依存する測定結果となっているが, 露光 $\mathrm{GC}$ 試料の強度は, 同一延伸倍率でも変動が大きい. そこでFig. 3 に, シート成形時の溶液濃度に対し, 各延伸 倍率ごとの最大強度の測定值をプロットした. 露光した $\mathrm{GC}$ 試料の強度は, 延伸倍率によってデータに拡がりがあ るが, 平均值をみると調製時の溶液濃度に依存している と言うことができる。これは特に低濃度側で顕著である.

試料の延伸に伴う強度の上昇挙動には, 試料の分子間 絡み合い密度が影響すると考えられている. 未露光試料 において, 同じ濃度の高分子溶液から作製した GC 試料 が GSP 試料よりも強度の上昇率が幾分大きいのは [3], 溶 液冷却速度の違いによる.すなわち GSP 試料は, 溶液が 徐冷され結晶化する時に分子鎖同士の絡み合いが解きほ ぐれるため, $\mathrm{GC}$ 試料に比べ分子間絡み合い密度が小さく なるからである $[2,3]$. 分子間絡み合い密度の大きい $\mathrm{GC}$ 試料では, 延伸応力が分子絡み合い点を介して, 各分子 鎖へより効果的に伝播され，延伸に伴う分子鎖の引き伸 ばしが促進される.

また, 4 濃度段階の高分子溶液から作製した未露光 GC 試料では, 分子間絡み合い密度が異なるにも拘わらず延 伸に伴う強度上昇挙動に差が見られない(Fig.1)。これは, UHMW-PP1wt.\%以上の溶液から作製した延伸 GC 試料に は, 高濃度の溶液から作製した試料ほどシシケバブ構造 が多く存在すること, シシケバブ構造, 特にケバブ構造 が分子鎖引き伸ばしによる強度上昇を打ち消す働きをす るためである，と考えられる[4].

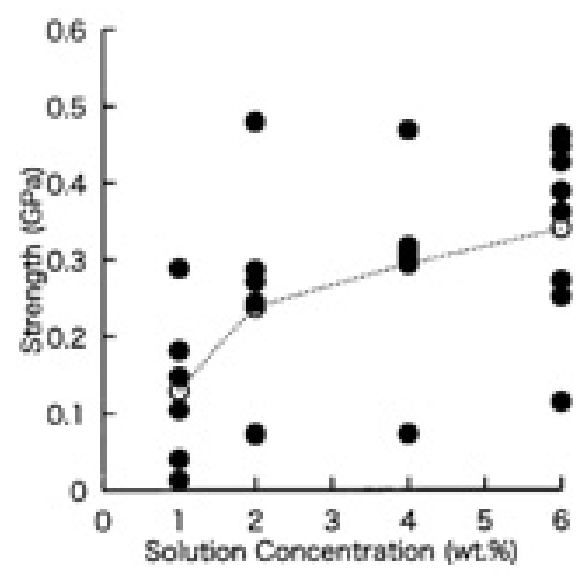

Fig. 3 Maximum tensile strength of the irradiated GC sheets of UHMW-PP versus solution concentration on casting the sheet $(\bigcirc$ : average strength). 
試料の強度を担っているのは，延伸によって長く引き 伸ばされた分子鎖であり，試料を露光することでこの分 子鎖が切断または分解されると, 強度が大きく低下する と考えられる. 露光時間が長くなり分子鎖の切断や分解 が進むにつれ，延伸試料の強度はシート成形時の溶液濃 度に拘わらず, 未露光未延伸シートの強度に近づいてい くと考えられる。したがって，強度におよぼす露光時間 と分子鎖切断速度の関係についての検討が今後必要であ ると思われる。

また，上述の通り GC 試料には，引き伸ばし分子鎖と ともにケバブ構造が混在していると考えられる. その他 にも, シート成形時の条件の相違により結晶化度の違い や分子絡み合いの点在, 延伸による繊維構造の形成と破 壊など, 試料の内部構造には不均一さが生じていると考 えられる. GC 試料および GSP 試料の紫外線透過率は, 試料によって差があったが、試料の厚さとの相関性は認 められなかった[12].このことから, 試料の内部構造の 不均一さが紫外線吸収の違いをもたらし, 結果として露 光後の試料の強度のバラツキを生じさせたと考えられる。 したがって, 延伸試料の微細構造と, それの紫外線吸収 に対する影響の解明も, 重要な検討課題であると思われ る.

\section{4. 結 言}

調製時のゲル冷却法の異なる超高分子量ポリプロピレ ン延伸テープをキセノンアーク灯光で露光して強度を測 定し, 次のことがわかった.

(1) 50 時間連続照射で，GC，GSP いずれの製法で調製し た試料も, 未露光試料に比べ強度が半分以下に低下す る.

(2) 1wt.\%以上の溶液から作製した GC 試料の露光による強 度変化においては, 未露光試料の傾向とは異なり, シー 卜作製時の溶液濃度すなわち試料の分子間絡み合い密
度の影響が現れる。

(3) GC 法, GSP 法とも試料の延伸倍率が大きくなると露 光による強度低下の割合が大きくなり, 光照射の影響 が大きく現れる．特に急冷法による GC 試料で強度低 下が大きい.

\section{謝 辞}

本研究を進めるに当たり, キセノンアーク灯光装置の 使用の便宜とご助言を賜りました愛媛県産業技術研究所 繊維産業技術センター主任研究員 檜坦誠司氏および中村 健治氏, また, 耐光試験条件についてご教示いただきま した東洋紡スーパー繊維事業部ダイニーマグループ 石川 靖子氏に深謝いたします。

\section{文 献}

1. http : //www.toyobo.co.jp/seihin/dn/dyneema/

2. T. Ohta, Y. Ikeda, M. Kishimoto, Y. Sakamoto, H. Kawamura and E. Asaeda, Polymer, 39, 4793 (1998).

3. Y. Ikeda and T. Ohta, Sen'i Gakkaishi, 58, 444 (2002).

4. Y. Ikeda and T. Ohta, Polymer, 49, 621 (2008).

5. http : //murata.mcg.co.jp/useful/index $01302 . \mathrm{html}$.

6. H. Yamamoto, Sen'i Gakkaishi, 61, 319 (2005).

7. L. Tang, Q. Wu and B. Qu, J Appl Polym Sci., 95, 270 (2005).

8. J. R. White and T.J. Turton, Polym Prepr., 42, 390 (2001).

9. R. K. Yadav and L. Shukla, Text Dyer Printer, 28, 15 (1995).

10. “JIS Standards”, Vol.31, Japanese Standards Association, Japan, p.581-605 (2008).

11. “JIS Standards", Vol.31, Japanese Standards Association, Japan, p.731-750 (2008).

12. Y. Ikeda and M. Komaki, unpublished. 